\title{
Teaching Method Innovation of Economic Management Course in the Internet Age
}

\author{
Qin Yang
}

Nanchang institute of technology,China

Keywords : Internet age, economic management, teaching, innovation

\begin{abstract}
With the development of Internet technology, the teaching of economic management course also has been greatly affected. Important changes have been made in teaching methods, teaching concepts and teaching modes, which have a certain effect on the teaching quality of economic management course, but also lead to some shortcomings.This paper discussed the teaching innovation of economics courses under the age of the Internet.

Teaching content of economic management course is relatively complicated, therefore, there are some difficulties in the teaching which the students to grasp the understanding, which will inevitably lead to the students' learning effect is not ideal. To analyze this phenomenon can be found that, on the one hand, the course of economics is far from our real life, so students in real life to the consciousness of problem for economics course is poorer, coupled with the economics course content is boring, students' interest in learning would be much less; on the other hand, because the traditional classroom teaching pattern is quite inflexible, teaching method is single, lack of interactive, students listen to sleep in class, there is no learning motivation. With the development of Internet technology, new teaching approaches to the teaching of economics courses. In class, the teacher can make use of Internet technology to teaching, is more vitality, is also more easy for students to understand, students' learning enthusiasm is higher, the teaching quality has been effectively improved.
\end{abstract}

\section{The existing problems in the teaching of economic management course}

Students access to information in a relatively simple way

Due to the influence of the traditional exam-oriented education in our country, the teaching pattern generally adopts the cramming teaching method, lead to the student's subjective initiative to be neglected, just passively accept, in this kind of teaching environment, effect of students in the classroom is not good. Although in recent years the teaching mode has made some reform, stress on cultivating the students' subjectivity, and through the guide way to cultivate the students' autonomous learning ability, but because of the bondage of the traditional teaching mode, lead to students' ability of independent access to materials in the learning process is weak, the way is single, usually only two kinds of way to access to data that is teaching materials and library for reference. In the process of check, due to the low efficiency, so students often spend a lot of time. Through active access to information, students' autonomous learning ability is greatly improved, students' understanding of the knowledge is more profound, more broad aspect of knowledge, however, due to the way of obtaining information is relatively simple, limiting the student's access to information. Students' learning enthusiasm and innovative ability are greatly restricted

With the development of Internet technology, students through the network for data access, the content is more abundant, and students spend less time, efficiency is higher, it has a better effect on students' learning. However, due to in networked world is full of temptation, it brought the negative impact to the students can not be ignored. After a lot of students through the information available on the Internet, will feel the teacher in the classroom teaching content is in repeat, no need to listen carefully, and then with the development of multimedia teaching promoted by application of Internet technology, need to play video, audio, pictures etc. in the teaching process, it will affect students concentrate in class, for the teaching summarize of teachers, students always think that they have learned anything, do not want to take notes, which leads to students' classroom 
knowledge is not solid, for what they have learned a little knowledge, affect the overall quality of teaching, also influence the teachers' teaching enthusiasm.

Another more common phenomenon is that whether it is job completion or teaching evaluation, students will find the basic knowledge of the Internet is the answer to the copy and paste. Most of the students completely copy from the Internet, in this process, don't move the brain, stereotyped, a lot of students, as well as the point of view of the way similar to the way from a template in the same. This way severely limited the development of the innovation ability for students, for students' learning and future employment will cause a lot of adverse effects.

\section{The innovation of teaching methods for economics courses in the Internet age}

Need to combine teaching theory with teaching practice

It is well known that Economics class teaching content is more abstract, compared with other subjects teaching content is more complex and difficult to understand. Therefore, if the students in the teaching process of the basic knowledge of the teaching is not strong, it will lead to students in the practice process can not be applied to teaching theory. So let the students grasp the basic knowledge of teaching is very important. In order to help students understand the basic teaching knowledge in the teaching content, the teacher must pay attention to combine teaching theory with method and teaching practice during the process of preparing lessons, according to the specific situation of the students to process teaching design. Abandon the traditional cramming teaching, which is just to instill knowledge to students, regardless of students to understand the situation of the knowledge. When teaching, teachers must systematically and comprehensively interpret the teaching content, let students can thoroughly understand the content of learning, and master them. For some special complicated knowledge, can use the Internet technology, such as multimedia teaching, demonstrate to students, make sure students can understand the content of teaching. It also can through the experimental teaching platform, such as ERP teaching management platform, e-commerce management platform and so on, let the students explore the teaching contents with the help of the platform. By using the network platform, can try to simplify the complicated knowledge points as simple as possible, so that the students can understand and remember it easily.

Through the Internet technology for questioning and answering online

In order to improve the interactivity between teachers and students, thus to improve the students' enthusiasm and initiative, to help students improve their study efficiency. Internet technology can be used to set up the way of questioning and answering online to enhance the interaction between teachers and students, so that students and teachers can maintain interaction outside the classroom, strengthen the emotional link between teachers and students. The traditional teaching mode focuses on instilling the knowledge, only teach the knowledge to students, and then let the students rote them, lack of interaction between teachers and students, lack of communication, cause the classroom atmosphere is indifference, the students' active degree is not high and teaching quality is not high, so in today's teaching process must strengthen the interactivity between teachers and students. By using Internet technology for questioning and answering online, can increase nearly degree of interaction between teachers and students, avoid the absence of time to interact with students due to the busy work of college teachers. And through the platform can achieve resource sharing and learning communication, so that students can learn and communicate the knowledge points which didn't understand in class, to improve the learning effect.

With the help of teaching software, to improve the teaching quality

With the help of the Internet technology can enrich teaching means and perfect the teaching system. Economics management courses teaching is different from other subjects teaching, so teachers must plan and design the teaching from the perspective of professional, combine basic knowledge with focus on the teaching content. In order to achieve better teaching effect in the teaching process,we can carry on the teaching through the professional teaching experiment software. Through teaching mode test software, can set up the teaching simulation network system, electronic commerce simulation system and economic management teaching experiment system, so that students can do actual simulation practice of the learned knowledge in the classroom, not only 
exercise the practice ability, but also strengthen the understanding of classroom knowledge, is an important and indispensable teaching method in the process of economic management teaching.

\section{Evaluation of the teaching methods for economic management in the Internet age}

In the Internet age, through the use of Internet technology to carry out economic management teaching can effectively enrich teaching means and improve the quality of teaching. But first must be clear the relationship between teaching and learning, this also put forward higher requirements to the teachers' comprehensive quality and ability. Teaching activity is a comprehensive use of a variety of teaching methods, including teaching mode, teaching content and teaching organization form, etc. This requires the teacher must have a certain forward-looking, should not only have the traditional thought, but also should have modern teaching thought, comprehensively plan the teaching for course. And students for the teachers' new teaching method will have a gradual process of adaptation. In the activities of teaching, students should take notes, and actively work on the teaching of teachers to complete the classroom teaching activities. This requires students to read some related teaching materials, broaden their horizons, reserve the professional knowledge, also asks the students to master the basic knowledge, in order to achieve good teaching effect in the classroom teaching activities. So in order to reform the teaching methods of economic management in the Internet age, and achieve better teaching results, so that teachers and students both sides are clear about the relationship between teaching and learning is very important.

The second is the technical support of teaching, the improvement of the teaching method can't be separated from the support of the teaching technology. In the Internet age, modern educational technology as the core of the computer technology is the core technology to improve the economics management teaching, such as multimedia technology used in teaching, etc. Through the application of these technologies can enrich the classroom teaching form, make the classroom teaching more vivid and interesting, the teaching content is also easier to understand, the student's learning enthusiasm is higher. Therefore, in the reform of the teaching methods of economics management courses in the Internet age, the corresponding teaching technology support is also an important aspect of teaching effect evaluation. In addition, the completion of the work for students, practice and innovation performance, etc. are also some important aspects of the teaching effect evaluation.

In summary, with the development of Internet technology, it provided a new way for teaching method reform of economic management course, enriched the teaching methods and improved the enthusiasm of students. But the application of Internet technology also had a lot of negative effects, influenced the teaching quality. In the teaching process, teachers should treat correctly, to guide students to improve the teaching quality of the economic management course.

\section{References}

[1] Xiaona Zhou, Jianfeng Wu. Thinking on the teaching methods innovation of economics management courses in the Internet age $[\mathrm{J}]$. Journal of contemporary education practice and teaching research, 2016,08:95.

[2] Yuhong Xie. Thinking on the teaching methods innovation of economics management courses in the Internet age [J]. Journal of Sun Yatsen University Forum, 2016,6: 7-11.

[3] Yonghui Zhang, Quansheng Meng. Application of inquiry learning method in the teaching of economics management courses in Colleges and Universities -- a case study on the teaching innovation of International Finance [J]. Journal of Higher Education Forum, 2014, 04:77-80.

[4] Ping Zhang. Exploration on the reform of economic management specialty course in Higher 
Vocational Colleges [J]. Journal of Shanxi Science and Technology, 2015, 02:92-94.

[5] Zhuli Wang, Xiaoyu Li, Jin Lin. Intelligent mobile phone and "Internet +" classroom — new thinking and new path of the integration for information technology and teaching [J]. Journal of Distance Education, 2015,04:14-21.

[6] Guifang Gu, Longjian Guo, Wen Li. The influence of Internet on the teaching of management courses and the choice of teaching methods [J]. Journal of Heilongjiang Education (higher education research and evaluation), 2014,05:65-66. 